\title{
Methodology For Assessing The Effectiveness of Regional Infrastructure Facilities to Support Scientific, Technical and Innovation Activities In The Context of The Synergy Effect: Analysis, Formation and Study
}

\section{Vladimir Byvshev}

Siberian Federal University: Sibirskij federal'nyj universitet

Kristina Parfenteva ( $\sim$ Kristina.Parfe@yandex.ru )

Krasnoyarsk regional fund for support of scientific and technical activities https://orcid.org/0000-00032991-2129

\section{Irina Panteleeva}

Siberian Federal University: Sibirskij federal'nyj universitet

\section{Danil Uskov}

Siberian Federal University: Sibirskij federal'nyj universitet

Vadim Demin

Siberian Federal University: Sibirskij federal'nyj universitet

\section{Research}

Keywords: infrastructure for the support of scientific, technical and innovation activities, regional economy, assessment methodology, innovation activity

Posted Date: November 23rd, 2021

DOI: https://doi.org/10.21203/rs.3.rs-1085498/v1

License: (c) (i) This work is licensed under a Creative Commons Attribution 4.0 International License. Read Full License 


\section{Abstract}

The aim of the study is to develop a methodology for assessing the effectiveness of the regional infrastructure facilities to support scientific, technical and innovation activities, taking into account the synergy effect. The article analyses methods existing in Russia and other countries and identifies their benefits and drawbacks. Based on the analysis conducted, the authors have determined a list of indicators characterising this area, developed a system for calculating the integral indicator, identified a list of regions that provided for the most objective assessment and testing of the developed methodology, and drew conclusions based on the calculations results. As a result, the effectiveness and perspectiveness of the developed methodology have been indicated. Even though the composite index is in the stability zone, its individual components may be in the zone of catastrophic risk and contain potential threats to further innovative development of a region. At the same time, it has been determined that regulatory support, as well as closed nature of the innovation cycle (synergy effect) play an important role in the efficient functioning of the infrastructure for supporting scientific, technical, and innovation activities.

\section{Introduction}

The COVID-19 pandemic has aggravated the global innovation race, and developed countries commit significant intellectual and financial resources to developing a coronavirus vaccine. The question of who will be the first to develop and launch the serial vaccine production is not only a matter of national health and safety, but an indicator of a state's innovative development and the ability of its innovation system to respond to global crises. The Russian Federation is the only one of the BRICS countries which was among the first to develop and launch large-scale vaccine production within a short period. Active implementation of innovations that can ensure the knowledge economy development is a priority direction of the state policy in the Russian Federation, however, innovative development at the state level is not possible without ensuring balanced regional development. Uneven spatial development of the Russian Federation, as well as the strengthening of regional differentiation are the factors that prevent balanced regional development and formation and development of the regional infrastructure for supporting scientific, technical and innovation activities, which should contribute to eliminating the existing imbalances by creating favourable conditions for the development and further use of innovations, play an important role in this regard (Zollo, G. et al.,

2011; Filipishyna, L. et al., 2018; Veselovsky, M. Y. et al., 2019; Rezk, M. A. et al., 2016; Rezk, M. A. et al., 2015; Firsova, A. A. et al., 2020; Colombelli, A. et al., 2020).

Having formed the necessary infrastructure, one cannot expect an immediate and effective return, as well as a quick solution to the existing problems. Studies indicate that the result from the infrastructure functioning can be seen in 5 years, provided that deadlines for the implementation of the relevant plans for conducting innovation are met and there is interaction with the innovation market participants (Parrilli, M. D. et al., 2020; Bezpalov, V. V. et al.2019; Kiškis, M. et al. 2016; Laužikas, M. et al., 2016; Ascani, A. et al., 2020).

To make the infrastructure function efficiently and perform the functions assigned to it, it is necessary to assess its performance with the subsequent adjustment of the disadvantageous processes. Such an assessment can be carried out with the use of specialised methodologies. The purpose of the study is to 
find an optimal methodological approach to studying the efficiency of not individual elements of the regional infrastructure, but their work as a whole, taking into account the synergy effect from closedness of the entire innovation chain. Currently, there is a significant number of different methodologies in the world that take into account their national and regional aspects, and some methodological approaches to conducting such an assessment are to be considered.

\section{Current Practices Analysis}

A composite innovation index of American counties (Based Economy. U.S. Economic Development Administration) is calculated in the United States. The index consists of four blocks, each of which is of different significance: human capital (30\%), economic dynamics (30\%), productivity and employment (30\%), as well as well-being (10\%). The index combines both the resources of innovation and its results (Statsamerica, 2009)

The Adam Smith International (ASI) methodology, which consists of 5 stages (1. Infrastructure costs assessment, 2. Process assessment, 3. Output assessment, 4. Results assessment, 5. Impact assessment) is also worth noting. In this way, at the stage of costs, the amount of necessary investments to create, for example, technical support that meets the list of the necessary standards is assessed. The process stage involves the achievement of target indicators in providing services by the infrastructure to support scientific, technical and innovation activities. At the stage of output, an analysis of the satisfaction with the innovative companies' infrastructure is carried out. The main results of such an infrastructure functioning can be technologies diffusion, R\&D quality improvement, etc. The final stage is the impact, an excellent indicator of which can be an assessment of the degree of economic integration into international markets (Assets publishing service, 2012).

Chinese scientists led by Fang Chuanglin proposed a methodology for assessing innovative development of territories. The researchers have developed four levels of indicators that reflect the composite innovation index assessment: 4 indicators at the second level, 10 at the third level, and 55 at the fourth one. Technology Innovation Index (B1), for instance, includes the Innovation Platform Construction Index (C1), the Innovation Factor Output Index (C2) and the Innovation Achievement Transfer Index (C3), which, in turn, are calculated through a number of indicators, for example, the number of higher education institutions per million people (D1), the number of national engineering research centres per million people (D3), the number of national innovation incubators per million people (D7), the number of post-doctoral research work stations per million people (D9), the number of innovation patents per million people (D17), etc. The benefits of the proposed methodology include the approach integrity and a significant number of indicators for measuring (Fang, C. et al., 2014).

One of the approaches to assessing the effectiveness of the infrastructure to support scientific, technical and innovation activities in the European Union, is the "Guide to Cost-Benefit Analysis of Investment Projects" of the European Commission. The need for an assessment using the cost analysis method is determined by the increased requirements for the efficient spending of budget funds in the field of innovation. The methodological approach of the European Commission lies in identifying three target 
groups of the infrastructure beneficiaries: innovative business, universities and scientific organisations, and society as a whole. The main factors to be considered in the process of assessing the infrastructure effectiveness are:

the number of innovative businesses created due to the infrastructure;

the expected amount of annual profit an average innovative business will generate, taking into account specific features of an industry and a region;

viability of the businesses started;

number of scientific publications reflecting new scientific results (Ascani, A. et al., 2020; Mel'nikov, R. M. 2015; Florio, M. et al., 2014; Del Bo Ch. 2014; Carrazza, S. et al., 2014).

This approach gives an opportunity to assess the infrastructure effectiveness, both in terms of commercialisation and growing businesses, as well as in terms of academic science and its success in the field of new discoveries.

Another methodology for assessing innovative development used in the EU is the European Innovation Scoreboard, based on the system of 29 indicators, with Regional Innovation Scoreboard of 16 indicators created on its basis later. Both systems include three blocks of indicators - factors of innovative development, companies' activities, and innovation results. According to the assessment results, the European Union regions are divided into fou types: innovation leaders, strong innovators, moderate innovators, moderately modest innovators and modest innovators (Kudriavtseva, S.S. 2012).

Methods for assessing the regional infrastructure for supporting scientific, technical and innovation activities of Russian researchers are reduced only to the analysis of the innovative development of a region. This trend may be associated with the emergence of several challenges in the selection of the necessary indicators due to the large number of infrastructure facilities in the regions and simultaneous impossibility to apply identical indicators that can correctly assess these facilities functioning. At the same time, it is impossible to ignore the fact that the innovation process in the region, as a rule, is carried out due to the innovation climate, which is largely determined by the regional infrastructure functioning. Based on this statement, it is possible to conclude that its assessment should be inseparable from the assessment of the innovation process which functioning it provides.

Indeed, V.A. Barinova, A.A. Maltceva, A.V. Sorokina and V.A. Eremkin (Barinova, V. A. et al., 2014) note the relationship between the level of innovative development and the number of support infrastructure facilities in Russian regions. The authors propose a calculation based on an approximation model for each level of a region's innovative development of the relevant number of support infrastructure facilities. Researchers note the presence of a nonlinear relationship between the level of innovative development of a region and the number of infrastructure facilities relevant to it.

Another assessment method is the approach by N.A. Porosyatnikova (Porosyatnikova, N. A. 2011), which proposes monitoring the state of innovation activity. Its results are presented as indicators, differentiated 
into several groups, reflecting the degree of development, flexibility and productivity of the support infrastructure. Examples of such indexes and indicators include: the ratio of commercialised developments, profit and revenue flexibility coefficients, the territories' knowledge intensity indicator, infrastructure density, etc.

A.A. Rumyantsev studies the dynamic indicators that characterise the innovation space of the macroregion of the Northwestern Federal District. He highlights the existing conditions for the scientific and innovative development of peripheral regions based on their own resources and their rapprochement with the leader, studies the growth factors underlying the scientific potential of peripheral territories, and pays special attention to the activities of local educational and research organisations (Rumyantsev, A. A. 2015).

The methodology of I.V. Pan'shin and T.N. Kashitsyna (Pan'shin, I.V., Kashitsyna T.N. 2009) is more comprehensive, from the point of view of the classification validity, systematisation and assessment of the components of the infrastructure for supporting scientific, technical and innovation activities in a region, as well as the choice of indicators characterising the state and effectiveness of its functioning. According to the authors, it allows not only to comprehensively study the level of development of the infrastructure for supporting scientific, technical and innovation activities, but also to ensure the possibility of universal application of the methodology for most regions of the Russian Federation. In the study, an integral indicator, which is differentiated according to the types of the elements of the infrastructure for supporting scientific, technical and innovation activities is formed.

A similar position is taken by NIAC MIIRIS (Miiris). Within the framework of this approach, the integration into a single system of assessing the functioning of the regional infrastructure for supporting scientific, technical and innovation activities and its innovation system is carried out.

A specific feature of this methodology is the use of both absolute and relative indicators. Since the use and calculation of indicators only in absolute values cannot provide an exhaustive picture of the issue under study due to inability to determine relations and influence, as well as to compare data.

Summing up the existing methodologies analysis, it can be noted that the authors assess both the innovation activity of the region as a whole and the indicators reflecting the efficiency of the support infrastructure functioning. However, there is a threat of problems that can arise in the process of finding sources for the indicators' calculation, due to the lack of data in the public domain. In addition to that, the analysed methodologies do not take into account qualitative and quantitative composition of the regional support infrastructure, as well as the issue whether is it necessary and sufficient in the form it is presented in the region under analysis, or if the strengthening of any infrastructure facilities is required, and if the quantity and the quality of support infrastructure facilities in a region is sufficient, then undoubtedly there is the synergy effect of their activities, since, as a result, the entire innovation chain in a region works at its every stage. It should be noted that another drawback of these methodologies is the fact that they do not take into account regional innovation legislation and its existence, and if it exists, then whether it is sufficiently developed for the barrier-free development of innovation in a region. 


\section{Methods And Approaches}

Having analysed foreign and domestic approaches to assessing regional infrastructure for supporting scientific, technical and innovation activities, it is offered to develop a new methodology with the following advantages over the aforementioned ones:

- its complex nature - a comprehensive reflection of the effectiveness of the infrastructure for supporting scientific, technical and innovation activities, taking into account the synergy effect from the activities of the entire infrastructure, which is not taken into account in the aforementioned methodologies;

- sufficiency - the assessment system is limited by the required number of indicators that can fully characterise the state and effectiveness of the infrastructure for supporting scientific, technical and innovation activities, including the regulatory component, which is not taken into account in the aforementioned methodologies;

- information support - the assessment is based on open and accessible statistical information;

- practical applicability - possibility to use the assessment system not only within the study, but also by regional authorities in constant work to adjust strategic and regulatory documentation, as well as to improve the mechanisms of regional innovation policy (Ruiga, I. R., et al., 2019)

At the first stage, a system of indicators for assessing the performance of infrastructure facilities for supporting scientific, technical and innovation activities is formed, and they are grouped according to areas. The groups of indicators and threshold values given in Table 1are offered as areas. 
Table 1

Indicators for assessing the infrastructure for supporting scientific, technical and innovation activities in a region in three differentiated areas

\section{Indicator}

\section{Threshold Threshold value \\ value source}

Information source

\section{Regulatory support}

Presence of a strategic planning document developed within the framework of goal setting

$0 / 1$

Authors'

Open

value sources

Presence of strategic planning document developed within the framework of programming (state programmes of a constituent entity of the RF)

0/1 Authors'

value

Presence of a specialised legislative act of a constituent entity of the RF

0uthors'
value

2. Infrastructural support

Providing the region with a complex of infrastructure elements to support scientific, technical and innovation activities.

The share of infrastructure facilities to support scientific, technical and innovation activities in the total number of organisations carrying out research and development (infrastructure support optimality), \%.

$\begin{array}{lll}\text { Not less } & \text { Authors' } & \text { Open } \\ \text { than } 2 & \text { calculation } & \text { sources }\end{array}$

$60-75 \% \quad$ Authors' calculation

\section{Potential of a region in the field of science and innovations}

Ratio of government expenditure on education to GRP, \%.

Share of labour force with higher education employed in economy, \%.

Share of personnel engaged in scientific research and development in the total amount of employed population, \%

Share of researchers with a scientific degree in the total number of personnel engaged in scientific research and development, \%.

Innovative activity of organisations, \%.

\begin{tabular}{lll}
$\begin{array}{l}\text { Not less } \\
\text { than 5 }\end{array}$ & $\begin{array}{l}\text { I.P. } \\
\text { Savel'eva }\end{array}$ & $\begin{array}{l}\text { Open } \\
\text { sources }\end{array}$ \\
\cline { 1 - 2 } $\begin{array}{l}\text { Not less } \\
\text { than 40 }\end{array}$ & $\begin{array}{l}\text { Authors' } \\
\text { calculation }\end{array}$ \\
\cline { 1 - 2 } $\begin{array}{l}\text { Not less } \\
\text { than 2 }\end{array}$ & $\begin{array}{l}\text { Authors' } \\
\text { calculation }\end{array}$ \\
\cline { 1 - 2 } $\begin{array}{l}\text { Not less } \\
\text { than 13.6 }\end{array}$ & $\begin{array}{l}\text { Authors' } \\
\text { calculation }\end{array}$
\end{tabular}

Not less than 12.5
O.I. Mityakova

S.N. Mityakov

4. Commercialisation and effectiveness of scientific and innovation activities in a region Technological innovations' cost intensity, \%.

Not less than 3.2
O.I.

Mityakova

S.N. Mityakov
Share of internal operating expenses for fundamental research in the total operating expenses, \%.
Not less

than 17.5
Authors'

calculation
Open sources 


\begin{tabular}{|lll|}
\hline Indicator & $\begin{array}{l}\text { Threshold } \\
\text { value }\end{array}$ & $\begin{array}{l}\text { Threshold } \\
\text { value } \\
\text { source }\end{array}$ \\
\hline $\begin{array}{l}\text { Share of internal current expenditures on scientific research } \\
\text { and development in total current expenditures, \%. }\end{array}$ & $\begin{array}{l}\text { Not less } \\
\text { than 67.5 }\end{array}$ & $\begin{array}{l}\text { Authors' } \\
\text { source } \\
\text { calculation }\end{array}$ \\
\hline $\begin{array}{l}\text { Share of internal operating expenditures for applied research } \\
\text { in total operating expenditures, \%. }\end{array}$ & $\begin{array}{l}\text { Not less } \\
\text { than 15 }\end{array}$ & $\begin{array}{l}\text { Authors' } \\
\text { calculation }\end{array}$ \\
\hline $\begin{array}{l}\text { Ratio of the volume of shipped innovative goods and } \\
\text { technological innovation cost, times }\end{array}$ & $\begin{array}{l}\text { Not less } \\
\text { than 5 }\end{array}$ & $\begin{array}{l}\text { V.K. } \\
\text { Senchagov }\end{array}$ \\
\hline $\begin{array}{l}\text { Share of developed advanced production technologies in the } \\
\text { total volume of advanced production technologies used, \%. }\end{array}$ & $\begin{array}{l}\text { Not less } \\
\text { than 1 }\end{array}$ & $\begin{array}{l}\text { Authors' } \\
\text { calculation }\end{array}$ \\
\hline $\begin{array}{l}\text { Rate of inventive activity (number of patent applications filed } \\
\text { with Rospatent per 10 thousand people) }\end{array}$ & $\begin{array}{l}\text { Not less } \\
\text { than 5 }\end{array}$ & $\begin{array}{l}\text { O.I. } \\
\text { Mityakova } \\
\text { S.N. } \\
\text { Mityakov }\end{array}$ \\
\hline
\end{tabular}

The normative documents provided for the first group of indicators lay the foundation for regional innovative development and efficiency of the support infrastructure functioning and make it possible to improve conditions for the further integration of scientific and production processes. Regulatory support in the field of science and innovation should be focused not only on the adoption of specific regulatory acts, but also on their actualisation, which is determined by the complex nature of the field of science and innovation (Bondarev, S.A., Turina, V. Yu. 2011). Specificity of determining normative values for this group of indicators is determined by the presence or absence of a valid document. Accordingly, it can be equal to one or zero (in case if such support is not provided in the region).

The group of infrastructure support indicators is formed according to the level of provision of a region with infrastructure facilities to support scientific, technical and innovation activities. It relates to the fact that infrastructure must be integral, which lies in the state of integration of all the necessary elements for the completed innovation process implementation. Thus, the absence of a necessary element in a region at a certain stage of the innovation process will indicate of a "gap" in the range of services provided and the lack of full support for the innovation project implementation by its facilities (Dalekin, P.I. 2018; Koroleva, L. P., Ermoshina, T.V. 2014).

Assessment of the infrastructural support of the regional infrastructure for supporting scientific, technical and innovation activities should be carried out with a focus on the innovation process logic, since it is necessary to support innovation initiatives at all its stages for the stable development of a region. In this regard, it is reasonable to systematise the infrastructure elements according to their belonging to the five stages of the innovation process (Figure 1) (Ivashchenko, N.P., Denisova, S.A.)

Peculiarity of assessing provision of the region with the infrastructure for supporting scientific, technical and innovation activities is determination of normative values for each of its elements. In this way, in case of the presence of facilities included in its composition, such an element of the infrastructure for supporting 
scientific, technical and innovation activities is given a normative value equal to one. If there is a lack of any infrastructure element in a region, the normative value, respectively, equals to zero (Figure 2).

In case of availability of the entire set of elements in the region, it is concluded that the infrastructure for supporting scientific, technical and innovation activities is an integral system that provides support to the innovation activity subjects at all stages of the innovation process. In this way, there is a synergy effect, and one additional point is allocated to such a region when calculating specific indicators for this subgroup. This effect is manifested in the increased efficiency of the functioning of the regional infrastructure for supporting scientific, technical and innovation activities in the process of interaction and integration of each of its elements into a coherent system for achieving a common goal. This, in turn, may indicate a significant increase and strengthening of the level of innovative development of a region (Ivanova, I. 2019).

Due to differentiation of the constituent entities of the Russian Federation according to the above factors, the assessment of the sufficiency and optimality of the provision of the infrastructure facilities of regions should be carried out using a relative indicator (Figure 2), equal to the ratio of the number of infrastructure facilities to the total number of organisations carrying out research and development.

The group of indicators of a region's potential in creating innovations is based on the statistical characteristics of the staffing and human capital of a region, as well as the state's financial investment in education. Human resources and human capital are the main factors contributing to the development of the potential of the sphere of science and innovation, since these are people who drive ideas for innovation and make discoveries in science, but not equipment and financial investments. Building long-term relationships between government departments and researchers is of particular importance. Research shows that the territories with the greatest number of innovations have a higher potential for staffing innovative activities Khuchbarov, A. U. 2015; Semenov, E. V. 2007; Kremer, M. 2020; Bell, A. et al., 2019).

The group of indicators of commercialisation and the effectiveness of scientific and innovative activities of a region reflects the parameters of financing the sphere of science and innovation, proactiveness in innovations and advanced technologies development, as well as the subsequent manufacturing of innovative products. The choice of these indicators is based on their ability to assess the effectiveness of the sphere of science and innovation in a region.

Calculation of threshold values for the fourth group of indicators is carried out by calculating the average values for the total number of regions of the Russian Federation (Loginov K.K. 2015). However, within the framework of this study, to avoid distortion and underestimation of threshold values, data of regions with a consistently low and constantly deteriorating in dynamics level of innovative development were not included in the calculation.

Thus, the threshold values were determined on the basis of the statistical data from the regions occupying high positions according to the data of rating agencies studying regional innovative development, such as RIA Rating (Official Website of The Rating Agency "RIA Rating"), The Association of Innovative Regions of Russia (Official Website of Association of Innovative Regions of Russia), Expert RA (Official Website of The Rating Agency "Expert RA"), as well as statistical studies of the economics of knowledge of the National 
Research University Higher School of Economics (Gokhberg, L. M. et al., 2020). To obtain objective results, the data for a five-year period from 2014 to 2018 in 15 innovatively developed regions have been analysed.

After the selection of the necessary indicators and normative values for them, at the second stage of the study it is necessary to calculate specific indicators for assessing the activities of the infrastructure for supporting scientific, technical and innovation activities according to the formulas $(1,2)$.

When calculating specific indicators, within the second stage the indicators were normalised (Mityakov, E. S., Mityakov, S. N. 2014; Mityakov, E. S. 2018). Application of this normalising function makes it possible to expand the dynamic range of the results visualisation. Since, within the selected indicators, threshold values of two types: "not more than" and "not less than" are used, one of the options for choosing a function for a ratio of "not less than" type is the function in the formula (1):

$$
\mathrm{I}^{\mathrm{r}}=\frac{1}{\mathrm{n}} \sum_{\mathrm{i}=1}^{\mathrm{n}}\left\{\begin{array}{l}
2^{\left(1-\frac{\mathrm{a}_{i}^{\mathrm{r}}}{\mathrm{x}_{\mathrm{i}}^{\mathrm{r}}}\right) / \ln \frac{10}{3}}, \text { если } \frac{\mathrm{x}_{1}^{\mathrm{r}}}{a_{\mathrm{r}}^{\mathrm{r}}}>1 ; \\
2^{-\log _{10} / 3 \frac{\mathrm{a}_{\mathrm{i}}^{\mathrm{r}}}{\mathrm{x}_{\mathrm{f}}^{\mathrm{r}}}}, \text { если } \frac{\mathrm{x}_{i}^{\mathrm{r}}}{a_{\mathrm{r}}^{\mathrm{r}}} \leq 1,
\end{array}\right.
$$

Accordingly, the ratio of "not more than" type uses the function reflected in formula (2):

$$
\mathrm{I}^{\mathrm{r}}=\frac{1}{\mathrm{n}} \sum_{\mathrm{i}=1}^{\mathrm{n}}\left\{\begin{array}{c}
2^{\left(1-\frac{\mathrm{x}_{i}^{\mathrm{r}}}{\mathrm{a}_{\mathrm{i}}^{\mathrm{r}}}\right) / \ln \frac{10}{3}}, \text { если } \frac{\mathrm{x}_{\mathrm{i}}^{\mathrm{r}}}{a_{\mathrm{r}}^{\mathrm{r}}}<1 ; \\
2^{-\log _{10} / 3 \frac{x_{i}^{\mathrm{r}}}{\mathrm{a}_{\mathrm{i}}^{\mathrm{r}}}}, \text { если } \frac{\mathrm{x}_{\mathrm{i}}^{\mathrm{r}}}{a_{\mathrm{i}}^{\mathrm{r}}} \geq 1,
\end{array}\right.
$$

where $\mathrm{I}^{r}$ is a specific indicator for a group of indicators;

$\mathrm{n}$ is the number of indicators for a separate group;

$\mathrm{X}_{\mathrm{i}}^{\mathrm{r}}$ is the value of the i-th indicator in the region $\mathrm{r}$;

$\mathrm{a}_{\mathrm{i}}^{\mathrm{r}}$ is the threshold value of the i-th indicator in the region $\mathrm{r}$.

At the third stage, based on the calculated specific indicators, it is also necessary to calculate the broadbased index of the activity of the infrastructure for supporting scientific, technical and innovation activities, which is a weighted sum of normalised specific indicators according to formula (3):

$\mathrm{IR}^{\mathrm{r}}=\sum_{\mathrm{i}=1}^{\mathrm{n}} \frac{\mathrm{k}^{\mathrm{r}}}{\mathrm{p}} \times \mathrm{I}^{\mathrm{r}}$

where $\mathbb{R}^{r}$ is the broad-based index of the infrastructure for supporting scientific, technical and innovation activities of the region $r$; 
$\mathrm{p}$ is the weighting coefficient of specific indicators;

$k^{r}$ is the number of indicators included in each group;

$p$ is the total number of indicators for all groups;

$\mathrm{I}^{\mathrm{r}}$ is the same as in formula (1).

At the fourth stage, the obtained values of specific indicators and indices assessing the activities of the infrastructure for supporting scientific, technical and innovation activities are compared with the normative values given in Table 2 .

Table 2

Interpretation of the indicator values according to the degree of risk.

\begin{tabular}{|ll|}
\hline Interval & Interpretation \\
\hline $\mathrm{I}^{\mathrm{r}}\left(\mathrm{IR}^{\mathrm{r}}\right) \leq 0.25$ & Catastrophic risk zone \\
$0,25<\mathrm{I}^{\mathrm{r}}\left(\mathrm{IR}^{\mathrm{r}}\right) \leq 0.5$ & Critical risk zone \\
$0,5<\mathrm{I}^{\mathrm{r}}\left(\mathrm{IR}^{\mathrm{r}}\right) \leq 0.75$ & Significant risk zone \\
$0,75<\mathrm{I}^{\mathrm{r}}\left(\mathrm{IR}^{\mathrm{r}}\right) \leq 1$ & Moderate risk zone \\
\hline $\mathrm{I}^{\mathrm{r}}\left(\mathrm{IR}^{\mathrm{r}}\right)>1$ & Stability zone \\
\hline
\end{tabular}

A distinctive feature of the developed methodology is availability of all the indicators included into the calculation system, and consideration of not only quantitative but also qualitative indicators, in particular, regulatory support for innovation activities, as well as taking into account the synergy effect from the integrated functioning of the support infrastructure in the methodology.

\section{Results And Discussion}

The selection of regions for testing the methodology for assessing the effectiveness of infrastructure facilities for supporting scientific, technical and innovation activities was carried out on the basis of ranking regions by aggregate indices. The first group includes the leading region, as well as the regions whose aggregate index value differs from the leading region's value by not more than $20 \%$. Based on the level of development, the second group includes regions that are behind the leader region by more than $20 \%$, but not more than $40 \%$. The third group includes regions that are in the $41-60 \%$ interval, and the fourth group is more than $60 \%$ behind the leader. After that regions from each group were selected (Table 3 ). 
Table 3

Generalised rating

Region

Year

$\begin{array}{llllllllll}2009 & 2010 & 2011 & 2012 & 2013 & 2014 & 2015 & 2016 & 2017 & 2018\end{array}$

Specific indicators of regulatory support

\begin{tabular}{lllllllllll} 
Moscow & 0.667 & 0.667 & 1.000 & 1.000 & 1.000 & 0.667 & 0.333 & 0.333 & 0.333 & 0.333 \\
$\begin{array}{l}\text { Saint- } \\
\text { Petersburg }\end{array}$ & 0.667 & 0.667 & 0.667 & 0.667 & 0.667 & 1.000 & 1.000 & 1.000 & 1.000 & 1.000 \\
\hline The Republic & 0.667 & 1.000 & 1.000 & 1.000 & 1.000 & 1.000 & 1.000 & 1.000 & 1.000 & 1.000
\end{tabular}
of Tatarstan

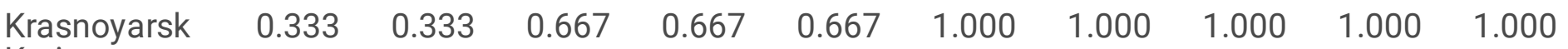
Krai

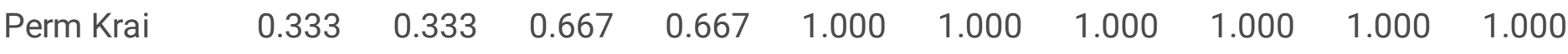

$\begin{array}{lllllllllll}\text { Volgograd } & 0.667 & 0.667 & 0.667 & 0.667 & 0.667 & 1.000 & 1.000 & 1.000 & 1.000 & 1.000\end{array}$

Oblast

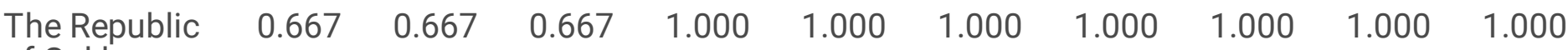
of Sakha

(Yakutia)

$\begin{array}{lllllllllll}\text { Bryansk } & 1.000 & 1.000 & 1.000 & 1.000 & 0.667 & 1.000 & 1.000 & 1.000 & 1.000 & 1.000\end{array}$

Specific indicators of infrastructure support

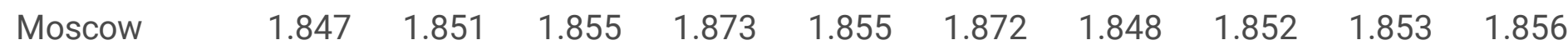

$\begin{array}{lllllllllll}\text { Saint- } & 1.831 & 1.838 & 1.835 & 1.840 & 1.843 & 1.848 & 1.851 & 1.852 & 1.854 & 1.854\end{array}$

Petersburg

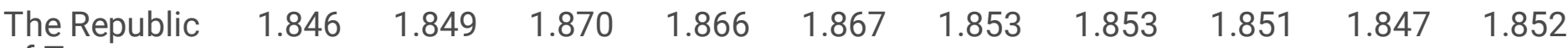
of Tatarstan

$\begin{array}{lllllllllll}\text { Krasnoyarsk } & 1.838 & 1.848 & 1.874 & 1.870 & 1.866 & 1.866 & 1.841 & 1.840 & 1.844 & 1.835\end{array}$ Krai

$\begin{array}{lllllllllll}\text { Perm Krai } & 1.847 & 1.872 & 1.874 & 1.847 & 1.873 & 1.851 & 1.840 & 1.845 & 1.846 & 1.847 \\ \begin{array}{l}\text { Volgograd } \\ \text { Oblast }\end{array} & 1.856 & 1.853 & 1.850 & 1.874 & 1.848 & 1.838 & 1.833 & 1.840 & 1.850 & 1.851\end{array}$

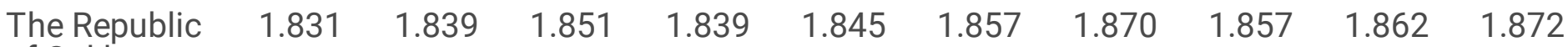
of Sakha

(Yakutia)

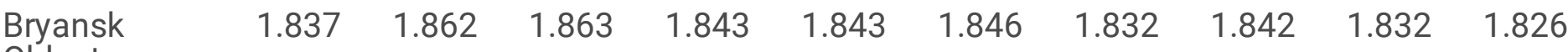
Oblast

Specific indicators of a region's potential to create innovations

$\begin{array}{lllllllllll}\text { Moscow } & 1.025 & 1.000 & 1.047 & 1.048 & 1.033 & 1.020 & 1.014 & 0.982 & 0.955 & 1.043\end{array}$ 


\begin{tabular}{|c|c|c|c|c|c|c|c|c|c|c|}
\hline \multirow[t]{2}{*}{ Region } & \multicolumn{10}{|l|}{ Year } \\
\hline & 2009 & 2010 & 2011 & 2012 & 2013 & 2014 & 2015 & 2016 & 2017 & 2018 \\
\hline $\begin{array}{l}\text { Saint- } \\
\text { Petersburg }\end{array}$ & 1.025 & 0.991 & 1.024 & 1.024 & 1.015 & 1.032 & 0.991 & 0.964 & 0.980 & 1.038 \\
\hline $\begin{array}{l}\text { The Republic } \\
\text { of Tatarstan }\end{array}$ & 0.798 & 0.798 & 0.834 & 0.850 & 0.881 & 0.900 & 0.873 & 0.885 & 0.891 & 0.909 \\
\hline $\begin{array}{l}\text { Krasnoyarsk } \\
\text { Krai }\end{array}$ & 0.813 & 0.752 & 0.764 & 0.775 & 0.800 & 0.775 & 0.765 & 0.741 & 0.730 & 0.762 \\
\hline Perm Krai & 0.845 & 0.824 & 0.748 & 0.778 & 0.767 & 0.774 & 0.759 & 0.723 & 0.697 & 0.746 \\
\hline $\begin{array}{l}\text { Volgograd } \\
\text { Oblast }\end{array}$ & 0.723 & 0.714 & 0.687 & 0.684 & 0.711 & 0.685 & 0.680 & 0.638 & 0.620 & 0.667 \\
\hline $\begin{array}{l}\text { The Republic } \\
\text { of Sakha } \\
\text { (Yakutia) }\end{array}$ & 0.877 & 0.910 & 0.918 & 0.916 & 0.950 & 0.958 & 0.923 & 0.924 & 0.917 & 0.923 \\
\hline $\begin{array}{l}\text { Bryansk } \\
\text { Oblast }\end{array}$ & 0.653 & 0.666 & 0.669 & 0.663 & 0.695 & 0.685 & 0.733 & 0.694 & 0.674 & 0.727 \\
\hline \multicolumn{11}{|c|}{ Specific indicators of commercialisation and results of innovation activity of a region } \\
\hline Moscow & 0.921 & 1.029 & 1.078 & 1.120 & 1.150 & 1.145 & 1.121 & 1.107 & 1.014 & 1.054 \\
\hline $\begin{array}{l}\text { Saint- } \\
\text { Petersburg }\end{array}$ & 1.073 & 1.102 & 1.124 & 1.131 & 1.137 & 1.130 & 1.069 & 1.083 & 1.068 & 1.058 \\
\hline $\begin{array}{l}\text { The Republic } \\
\text { of Tatarstan }\end{array}$ & 0.858 & 0.902 & 0.861 & 0.925 & 0.908 & 0.964 & 0.976 & 0.968 & 0.954 & 0.940 \\
\hline $\begin{array}{l}\text { Krasnoyarsk } \\
\text { Krai }\end{array}$ & 0.765 & 0.708 & 0.832 & 0.894 & 0.898 & 0.838 & 0.768 & 0.794 & 0.745 & 0.815 \\
\hline Perm Krai & 0.735 & 0.842 & 0.801 & 0.769 & 0.812 & 0.813 & 0.801 & 0.857 & 0.861 & 0.820 \\
\hline $\begin{array}{l}\text { Volgograd } \\
\text { Oblast }\end{array}$ & 0.794 & 0.782 & 0.712 & 0.622 & 0.602 & 0.644 & 0.680 & 0.662 & 0.700 & 0.668 \\
\hline $\begin{array}{l}\text { The Republic } \\
\text { of Sakha } \\
\text { (Yakutia) }\end{array}$ & 0.610 & 0.580 & 0.640 & 0.654 & 0.737 & 0.714 & 0.617 & 0.739 & 0.629 & 0.756 \\
\hline $\begin{array}{l}\text { Bryansk } \\
\text { Oblast }\end{array}$ & 0.908 & 0.818 & 0.838 & 0.860 & 0.806 & 0.850 & 0.875 & 0.874 & 0.829 & 0.731 \\
\hline \multicolumn{11}{|c|}{$\begin{array}{l}\text { Generalised indices of the infrastructure for supporting scientific, scientific and technical and innovation } \\
\text { activities in a region }\end{array}$} \\
\hline Moscow & 1.213 & 1.246 & 1.320 & 1.340 & 1.341 & 1.295 & 1.230 & 1.221 & 1.185 & 1.216 \\
\hline $\begin{array}{l}\text { Saint- } \\
\text { Petersburg }\end{array}$ & 1.259 & 1.264 & 1.277 & 1.281 & 1.282 & 1.332 & 1.305 & 1.305 & 1.303 & 1.311 \\
\hline
\end{tabular}




\begin{tabular}{|c|c|c|c|c|c|c|c|c|c|c|}
\hline \multirow[t]{2}{*}{ Region } & \multicolumn{10}{|l|}{ Year } \\
\hline & 2009 & 2010 & 2011 & 2012 & 2013 & 2014 & 2015 & 2016 & 2017 & 2018 \\
\hline $\begin{array}{l}\text { The Republic } \\
\text { of Tatarstan }\end{array}$ & 1.149 & 1.212 & 1.212 & 1.235 & 1.188 & 1.254 & 1.252 & 1.251 & 1.246 & 1.247 \\
\hline $\begin{array}{l}\text { Krasnoyarsk } \\
\text { Krai }\end{array}$ & 1.070 & 1.043 & 1.143 & 1.164 & 1.169 & 1.192 & 1.158 & 1.162 & 1.145 & 1.171 \\
\hline Perm Krai & 1.070 & 1.109 & 1.129 & 1.116 & 1.184 & 1.178 & 1.168 & 1.181 & 1.178 & 1.174 \\
\hline $\begin{array}{l}\text { Volgograd } \\
\text { Oblast }\end{array}$ & 1.116 & 1.109 & 1.080 & 1.058 & 1.047 & 1.101 & 1.110 & 1.098 & 1.111 & 1.110 \\
\hline $\begin{array}{l}\text { The Republic } \\
\text { of Sakha } \\
\text { (Yakutia) }\end{array}$ & 1.076 & 1.075 & 1.101 & 1.149 & 1.185 & 1.182 & 1.147 & 1.184 & 1.148 & 1.195 \\
\hline $\begin{array}{l}\text { Bryansk } \\
\text { Oblast }\end{array}$ & 1.182 & 1.163 & 1.171 & 1.170 & 1.110 & 1.172 & 1.185 & 1.180 & 1.158 & 1.133 \\
\hline
\end{tabular}

Assessment of the effectiveness of infrastructure facilities to support scientific, technical and innovation activities of Moscow

The generalised index of the infrastructure for supporting scientific, technical and innovation activities of Moscow was in the stability zone (Table 3 ), indicating that its functioning is quite efficient. However, significant shifts were observed for some groups of indicators. The decrease in the index of the regulatory group of indicators can be explained by the suspension of the Law of June 06, 2012 No. 22 "On Scientific, Technical and Innovation Activity in the City of Moscow", as well as the Decree of the Government of Moscow of June 26, 2007 No. 513-Пח "On The Development Strategy of The City of Moscow for The Period Up to 2025 ", in which one of the tasks within the framework of achieving the strategic goal of increasing competitiveness and innovative development of the region was effective functioning of the infrastructure for supporting scientific, technical and innovation activities. As noted by the mayor of the city, such a project was developed jointly with the research team of the Higher School of Economics in 2011, but the pace of the city development was higher than the pace of this document development.

At the same time, despite the absence of some regulatory acts, representatives of each of the infrastructure elements for supporting scientific, technical and innovation activities are present and developing in the city, which ensures the synergy effect. In addition to that, it is possible to consider quantitative distribution of infrastructure facilities according to the types of elements (Table 4). 
Table 4

Distribution of infrastructure facilities to support scientific, technical and innovation activities by elements in Moscow

\begin{tabular}{|c|c|c|c|c|c|c|c|c|c|c|}
\hline Element & 2009 & 2010 & 2011 & 2012 & 2013 & 2014 & 2015 & 2016 & 2017 & 2018 \\
\hline Financial & 15 & 17 & 23 & 25 & 31 & 32 & 33 & 33 & 36 & 36 \\
\hline $\begin{array}{l}\text { Production } \\
\text { and } \\
\text { technological }\end{array}$ & 90 & 100 & 114 & 126 & 133 & 142 & 153 & 167 & 184 & 191 \\
\hline Information & 8 & 8 & 8 & 8 & 8 & 8 & 8 & 8 & 8 & 8 \\
\hline $\begin{array}{l}\text { Expert and } \\
\text { consulting }\end{array}$ & 17 & 18 & 19 & 21 & 22 & 23 & 24 & 25 & 25 & 25 \\
\hline Personnel & 264 & 268 & 256 & 248 & 223 & 227 & 203 & 179 & 161 & 153 \\
\hline Sales & 5 & 7 & 6 & 8 & 8 & 9 & 10 & 9 & 11 & 10 \\
\hline $\begin{array}{l}\text { Optimality of } \\
\text { infrastructure } \\
\text { support }\end{array}$ & 0.927 & 0.959 & 0.982 & 1.110 & 0.985 & 1.103 & 0.933 & 0.961 & 0.969 & 0.992 \\
\hline
\end{tabular}

As can be seen from Table 4, representatives of each of the infrastructure elements can be found in Moscow, which indicates the support of all stages of the innovation cycle. However, there is an insufficient level of optimality of infrastructure support. Considering the data given, it can be noted that the largest number of facilities is in terms of personnel and production and technological infrastructure. Indeed, Moscow is the leader in terms of the number of leading educational organisations, including higher education and scientific organisations.

After consideration of the third group of Moscow indicators, it was noted that the indicator reflecting the ratio of government expenditure on education to GRP did not reach the normative value for the period of a decade (Figure 3).

As can be seen from Figure 3, with a stable growth of GRP, expenditure on education was not constant, to be exact, the decline was observed in 2013-2015. In addition, it is possible to compare the volume of such expenditures with the level of GRP and, thus, conclude that their share is insignificant and amounts to about $2.5 \%$. A significant share of budgetary expenditures is allocated to the national economy and federal issues.

To assess the fourth groups of indicators, research and development costs structure is to be considered (Figure 4).

Over the past decade, the largest costs have been research and development costs (with a big share of technical costs). This means that the largest volume of costs falls on such activities as design and planning work, development of technological processes, creation of prototypes and their testing, as well as engineering activities. This trend is directly related to the number and variety of infrastructure facilities for supporting scientific, technical and innovation activities in the production and technological element, contributing to these types of work. 
Assessment of the effectiveness of infrastructure facilities to support scientific, technical and innovation activities of St. Petersburg

Similarly to Moscow, the efficiency of the infrastructure facilities to support scientific, technical and innovation activities of St. Petersburg has been in the stability zone for a decade.

Since 2014, the regulatory support of the sphere of science and innovation in the city has covered the entire necessary range of documents that form the basis for both innovation activities in general and functioning of the infrastructure to support scientific, technical and innovation activities. In this regard, it can be noted that it was the adoption of the necessary acts that caused the increase in the generalised index in 2014 compared to the previous year.

As for the infrastructure support, it should be noted that a full range of infrastructure elements presented in Table 5 function in the city.

Table 5

Distribution of infrastructure facilities to support scientific, technical and innovation activities by elements in St. Petersburg

\begin{tabular}{|c|c|c|c|c|c|c|c|c|c|c|}
\hline Element & 2009 & 2010 & 2011 & 2012 & 2013 & 2014 & 2015 & 2016 & 2017 & 2018 \\
\hline Financial & 4 & 5 & 5 & 5 & 5 & 5 & 5 & 5 & 5 & 5 \\
\hline $\begin{array}{l}\text { Production } \\
\text { and } \\
\text { technological }\end{array}$ & 39 & 40 & 44 & 44 & 45 & 52 & 58 & 66 & 71 & 71 \\
\hline Information & 1 & 1 & 1 & 1 & 1 & 1 & 1 & 1 & 1 & 1 \\
\hline $\begin{array}{l}\text { Expert and } \\
\text { consulting }\end{array}$ & 6 & 7 & 7 & 8 & 8 & 8 & 9 & 9 & 9 & 9 \\
\hline Personnel & 89 & 90 & 84 & 82 & 77 & 77 & 76 & 71 & 66 & 66 \\
\hline Sales & 5 & 6 & 6 & 7 & 7 & 7 & 8 & 8 & 8 & 8 \\
\hline $\begin{array}{l}\text { Optimality of } \\
\text { infrastructure } \\
\text { support }\end{array}$ & 0.815 & 0.866 & 0.848 & 0.879 & 0.904 & 0.934 & 0.960 & 0.964 & 0.977 & 0.979 \\
\hline
\end{tabular}

The content of elements of the infrastructure to support scientific, technical and innovation activities of the city demonstrates provision of all stages of the innovation cycle. Considering the data presented, it can be noted that the largest number of facilities can be seen in terms of personnel and production and technological types of elements. In this regard, the number of the last element facilities are to be considered (Table 6). 
Table 6

Distribution of infrastructure facilities to support scientific, technical and innovation activities of the production and technological element of St. Petersburg

\begin{tabular}{|lllllllllll|}
\hline Facility & $\mathbf{2 0 0 9}$ & $\mathbf{2 0 1 0}$ & $\mathbf{2 0 1 1}$ & $\mathbf{2 0 1 2}$ & $\mathbf{2 0 1 3}$ & $\mathbf{2 0 1 4}$ & $\mathbf{2 0 1 5}$ & $\mathbf{2 0 1 6}$ & $\mathbf{2 0 1 7}$ & $\mathbf{2 0 1 8}$ \\
\hline Technoparks & 4 & 5 & 5 & 5 & 6 & 6 & 6 & 6 & 6 & 5 \\
\hline $\begin{array}{l}\text { Industrial parks } \\
\text { Clusters }\end{array}$ & 2 & 2 & 3 & 3 & 3 & 3 & 3 & 3 & 3 & 3 \\
\hline $\begin{array}{l}\text { Engineering } \\
\text { centres }\end{array}$ & 6 & 6 & 6 & 6 & 6 & 7 & 7 & 8 & 8 & 8 \\
$\begin{array}{l}\text { Business } \\
\text { incubators }\end{array}$ & 5 & 5 & 5 & 5 & 5 & 5 & 5 & 5 & 5 & 5 \\
$\begin{array}{l}\text { Special economic } \\
\text { zone }\end{array}$ & 1 & 1 & 1 & 1 & 1 & 1 & 1 & 1 & 1 & 1 \\
$\begin{array}{l}\text { Shared resource } \\
\text { centres }\end{array}$ & 17 & 18 & 21 & 21 & 22 & 27 & 30 & 34 & 39 & 40 \\
\hline
\end{tabular}

It can be summarised that the largest number of facilities belong to the shared resource centres, aimed at providing services for scientific research, as well as implementation of experimental development by providing scientific and technological equipment.

In addition to that, an accelerated growth in the number of clusters in the territory of the constituent entity of the RF should also be noted. The largest of them is the innovative territorial cluster "Development of Information Technologies, Radio Electronics, Instrumentation, Means of Communication and Information Telecommunications in St. Petersburg", which had more than 200 enterprises as of 2018.

However, having considered the ratio of infrastructure facilities for supporting scientific, technical and innovation activities, and the number of organisations carrying out research and development, it can be concluded that it is not entirely optimal, since on average it is $9 \%$ lower than the established normative value. In this regard, there is a need to increase the number of infrastructure facilities to support scientific, technical and innovation activities to correct this ratio.

The state of the third group of indicators was stable except for 2015-2017. It is connected with the differences in the growth rates of the region's GRP and expenditure on education.

The indicators of the fourth group were significantly reduced in 2015 . The reason for this was the excess of costs for technological innovations over the volume of manufactured products, which, according to experts, may indicate the low efficiency of technology transfer (Bondarenko, V. V. et al., 2018; Mityakov, E. S. 2018).

\section{Assessment of the effectiveness of infrastructure facilities to support scientific, technical and innovation activities of the Republic of Tatarstan}

The results in Table 3 indicate a relatively stable position of the Republic of Tatarstan in the efficiency of the infrastructure facilities for supporting scientific, technical and innovation activities, however, it is worth 
focusing on some groups of indicators.

The low value of the specific indicator in 2009 was determined, first of all, by some "gap" in the special legislative act of the constituent entity due to the presence of its draft. There is also the State Programme “Economic Development and The Innovative Economy of the Republic of Tatarstan for 2014-2021" which is implemented in the territory of the Republic, one of the tasks of which is to create conditions for the effective functioning of the innovation economics, including within the framework of the infrastructure for supporting scientific, technical and innovation activity.

Indeed, according to the block of indicators of the same name, it can be seen that it is at a consistently high level. This relates to the fact that there is the whole complex of infrastructure elements presented in Table 7 in the Republic.

Table 7

Distribution of infrastructure facilities to support scientific, technical and innovation activities by elements in the Republic of Tatarstan

\begin{tabular}{|c|c|c|c|c|c|c|c|c|c|c|}
\hline Element & 2009 & 2010 & 2011 & 2012 & 2013 & 2014 & 2015 & 2016 & 2017 & 2018 \\
\hline Financial & 1 & 1 & 1 & 2 & 3 & 3 & 3 & 3 & 3 & 3 \\
\hline $\begin{array}{l}\text { Production } \\
\text { and } \\
\text { technological }\end{array}$ & 12 & 15 & 15 & 20 & 25 & 30 & 32 & 30 & 34 & 34 \\
\hline Information & 15 & 15 & 15 & 18 & 18 & 18 & 18 & 18 & 18 & 18 \\
\hline $\begin{array}{l}\text { Expert and } \\
\text { consulting }\end{array}$ & 6 & 6 & 6 & 10 & 11 & 12 & 15 & 16 & 16 & 17 \\
\hline Personnel & 14 & 14 & 14 & 17 & 17 & 17 & 17 & 17 & 17 & 17 \\
\hline Sales & 1 & 1 & 2 & 3 & 2 & 3 & 3 & 3 & 4 & 5 \\
\hline $\begin{array}{l}\text { Optimality of } \\
\text { infrastructure } \\
\text { support }\end{array}$ & 0.923 & 0.946 & 1.087 & 1.059 & 1.070 & 0.971 & 0.974 & 0.954 & 0.930 & 0.962 \\
\hline
\end{tabular}

Availability of all elements testifies of the infrastructure support of the full cycle of the innovation process. The largest number of facilities can be seen in the information element. The Republic of Tatarstan is the leader in the Russian Federation in terms of the number of Technology and Innovation Support Centres, where inventors and researchers can use the closed databases of Rospatent free of charge.

In addition to the information element, other elements are developed in the entity as well. In 2012, the Technology Innovative Special Economic Zone "Innopolis" was created. This project is unique since the necessary conditions for comfortable living and work of young IT specialists, social infrastructure, as well as the provision of various preferential conditions are created at one site.

In addition, the study considered the indicator of the ratio of infrastructure facilities to support scientific, technical and innovation activities and the number of organisations carrying out research and development, 
which is generally in the zone of optimality, with the exception of 2009-2010 and 2014-2018, when its insignificant increase, with an excess of not more than $5 \%$, was observed.

Summarising the third and fourth groups of indicators, it can be noted that during the period under study they were in the moderate risk zone. This trend is primarily associated with a low share of people engaged in scientific research and development, however, despite not reaching the normative value for this indicator, the Republic of Tatarstan is one of the leading territories in innovative development, with a stable growth of inventive activity, as well as the number of advanced production technologies developed.

In addition, there is a problem of low demand for innovations in the region's economy, as well as its ineffective structure - an excessive bias towards the purchase of finished equipment abroad to the detriment of introducing their own new developments, as evidenced by the corresponding indicator.

\section{Assessment of the effectiveness of infrastructure facilities to support scientific, technical and innovation activities of Krasnoyarsk Krai}

The generalised index of the infrastructure for supporting scientific, technical and innovation activities of Krasnoyarsk Krai has undergone some changes (Table 3), and in this regard, it is reasonable to identify the reasons for such shifts.

The regulatory framework, which forms the basis for the development and functioning of the infrastructure for supporting scientific, technical and innovation activities is characterised by stepwise development. In this way, in 2009-2010, there was a lack of strategic planning documents at the regional level, in addition to this, there was no state programme in this area in 2009-2013. However, in 2011 and 2014 the situation changed after approving the Law of Krasnoyarsk Krai of 01.12.2011 No. 13-6629 "On Scientific, Technical and Innovation Activities in Krasnoyarsk Krai", as well as by approving the State Programme of Krasnoyarsk Krai "Development of Investment Activities, Small and Medium-Sized Businesses" for the period of 20142030. The programme describes the main directions of the state support for scientific, technical and innovation activities in creation and development of infrastructure facilities for supporting scientific, technical and innovation activities.

Considering the fullness of the elements with the infrastructure facilities for supporting scientific, technical and innovation activities (Table 8), it was found out that currently the area is not being implemented effectively enough. 
Table 8

Distribution of infrastructure facilities to support scientific, technical and innovation activities by elements in Krasnoyarsk Krai

\begin{tabular}{|c|c|c|c|c|c|c|c|c|c|c|}
\hline Element & 2009 & 2010 & 2011 & 2012 & 2013 & 2014 & 2015 & 2016 & 2017 & 2018 \\
\hline Financial & 2 & 2 & 2 & 3 & 3 & 3 & 3 & 3 & 3 & 3 \\
\hline $\begin{array}{l}\text { Production } \\
\text { and } \\
\text { technological }\end{array}$ & 9 & 10 & 13 & 14 & 15 & 16 & 16 & 17 & 17 & 17 \\
\hline Information & 3 & 3 & 3 & 3 & 3 & 3 & 3 & 3 & 3 & 3 \\
\hline $\begin{array}{l}\text { Expert and } \\
\text { consulting }\end{array}$ & 1 & 1 & 1 & 1 & 1 & 1 & 1 & 1 & 1 & 1 \\
\hline Personnel & 10 & 12 & 12 & 11 & 11 & 10 & 10 & 9 & 8 & 8 \\
\hline Sales & 1 & 1 & 1 & 1 & 2 & 2 & 2 & 2 & 2 & 2 \\
\hline $\begin{array}{l}\text { Optimality of } \\
\text { infrastructure } \\
\text { support }\end{array}$ & 0.863 & 0.938 & 1.119 & 1.093 & 1.061 & 1.061 & 0.886 & 0.879 & 0.908 & 0.846 \\
\hline
\end{tabular}

Since the beginning of the State Programme implementation, there have been no shifts with an increase in the number of infrastructure facilities, and the optimality of infrastructure support has also been unstable. An exception was the production and technological element, in which the children's technopark Quantorium, which is characterised by a unique environment for the accelerated development of children in research engineering and technical areas, with the use of high-tech equipment, has been operating since 2017.

Among the problems of the region, it is necessary to note low proportion of personnel engaged in research and development. This may be determined by a steadily decreasing number of students in higher education programmes, low motivation of young people to carry out activities in educational and scientific organisations, as well as a low level of employment in the field of innovations, which jointly entails a decrease in the level of inventive activity, the number of advanced technologies developed, etc. in the long run.

One of the reasons for the abovementioned negative trends is insufficient number of measures and state funding for scientific, technical and innovation activities in Krasnoyarsk Krai, which is also reflected in the programme document of the region.

In this regard, it is necessary to create new and develop existing support for infrastructure facilities, as well as to increase the level of integration and interaction between science and business.

\section{Assessment of the effectiveness of infrastructure facilities to support scientific, technical and innovation activities of Perm Krai.}

The generalised index of the infrastructure for supporting scientific, technical and innovation activities of Perm Krai during the period under study is in the moderate risk zone (Table 3). 
The development of the regulatory framework in the region was carried in a stepwise manner, similar to Krasnoyarsk Krai. Thus, in 2009 and 2010, there was no necessary strategic planning document. Moreover, from 2009-2012, there were no state programmes in this area. However, in 2011 and 2013, the relevant documents were approved. Thus, the state subprogramme of the State Programme "Economic Development and Innovation-Drive Economy" defines one of the tasks for achieving this goal as formation of an infrastructure to support scientific, technical and innovation activities, contributing to the accelerated creation and development of innovative enterprises.

Since 2013, there has been an increase in the facilities of the production and technological element of the infrastructure to support scientific, technical and innovation activities of Perm Krai (Table 9).

Table 9

Distribution of infrastructure facilities to support scientific, technical and innovation activities by elements in Perm Krai

\begin{tabular}{|c|c|c|c|c|c|c|c|c|c|c|}
\hline Element & 2009 & 2010 & 2011 & 2012 & 2013 & 2014 & 2015 & 2016 & 2017 & 2018 \\
\hline Financial & 2 & 3 & 3 & 3 & 3 & 3 & 3 & 3 & 3 & 3 \\
\hline $\begin{array}{l}\text { Production } \\
\text { and } \\
\text { technological }\end{array}$ & 7 & 8 & 11 & 11 & 12 & 13 & 13 & 15 & 15 & 16 \\
\hline Information & 1 & 1 & 1 & 1 & 1 & 1 & 1 & 1 & 1 & 1 \\
\hline $\begin{array}{l}\text { Expert and } \\
\text { consulting }\end{array}$ & 3 & 3 & 3 & 4 & 4 & 4 & 4 & 4 & 4 & 4 \\
\hline Personnel & 13 & 16 & 16 & 16 & 16 & 12 & 12 & 11 & 10 & 10 \\
\hline Sales & 1 & 1 & 1 & 1 & 1 & 1 & 1 & 1 & 1 & 1 \\
\hline $\begin{array}{l}\text { Optimality of } \\
\text { infrastructure } \\
\text { support }\end{array}$ & 0.932 & 1.105 & 1.116 & 0.932 & 1.113 & 0.960 & 0.878 & 0.916 & 0.924 & 0.931 \\
\hline
\end{tabular}

Within the framework of the state programme, a Cluster of Fibre Optics Technologies "Photonics" was created in 2014, and the "Pharmaceutical Cluster" of Perm Krai in 2016. The aim of their creation was hightech mass production of import-substituting pharmaceutical products, as well as expanding the geography of presence and sales volume of products of the cluster enterprises in the domestic and foreign markets. In 2017, the Industrial Cluster of Agricultural Machinery of Perm Krai was launched with the aim of developing the production of high-tech competitive equipment. However, as can be seen from Table 10, over the past five years (2014-2018), there was a lag from the normative value in terms of the optimality of infrastructure support, which indicates a decrease in the number of organisations engaged in research and development.

During the decade, the indicators of the fourth group were in the significant and moderate risk zones. Perm Krai is characterised by a pronounced shortage of scientific personnel, including researchers with a scientific degree. For the effective functioning of the innovation system the region needs twice as many specialists in this area. This directly indicates that there is a need to develop a personnel element of the infrastructure for supporting scientific, technical and innovation activities of the entity to increase the number of highly 
qualified personnel. Moreover, there is a problem of the lack of budgetary funds required for the implementation of the main measures to increase the level of innovative development of the region.

\section{Assessment of the effectiveness of infrastructure facilities to support scientific, technical and innovation activities of Volgograd Oblast}

Analysing Volgograd Oblast, it can be noted that the generalised index is in the significant and moderate risk zones. There was no state programme in the region for four years from 2009 to 2013 . However, it was approved in 2014, and has been implemented since that time. This document notes the lack of funds and infrastructure for innovation projects implementation among the subjects of innovation activity. The elements of the infrastructure for supporting scientific, technical and innovation activities of the region as a whole are demonstrated in Table 10.

Table 10

Distribution of infrastructure facilities to support scientific, technical and innovation activities by elements in Volgograd Oblast

\begin{tabular}{|lllllllllll|}
\hline Element & $\mathbf{2 0 0 9}$ & $\mathbf{2 0 1 0}$ & $\mathbf{2 0 1 1}$ & $\mathbf{2 0 1 2}$ & $\mathbf{2 0 1 3}$ & $\mathbf{2 0 1 4}$ & $\mathbf{2 0 1 5}$ & $\mathbf{2 0 1 6}$ & $\mathbf{2 0 1 7}$ & $\mathbf{2 0 1 8}$ \\
\hline Financial & 1 & 1 & 1 & 1 & 1 & 1 & 1 & 1 & 2 & 2 \\
\hline $\begin{array}{l}\text { Production } \\
\text { and } \\
\text { technological }\end{array}$ & 4 & 5 & 5 & 5 & 5 & 6 & 6 & 7 & 7 & 7 \\
\hline $\begin{array}{l}\text { Information } \\
\text { Expert and }\end{array}$ & 1 & 1 & 1 & 1 & 1 & 1 & 1 & 1 & 1 & 1 \\
\hline consulting & 1 & 1 & 1 & 1 & 1 & 1 & 1 & 1 & 1 \\
\hline $\begin{array}{l}\text { Personnel } \\
\text { Sales }\end{array}$ & 1 & 16 & 15 & 15 & 16 & 13 & 13 & 12 & 12 & 12 \\
\hline $\begin{array}{l}\text { Optimality of } \\
\text { infrastructure } \\
\text { support }\end{array}$ & 0.995 & 0.972 & 0.949 & 1.118 & 0.934 & 0.867 & 0.830 & 0.878 & 0.947 & 0.959 \\
\hline
\end{tabular}

Of all the above regions, the optimality of infrastructure support indicator in Volgograd Oblast is the lowest, with large deviations from the threshold value. In this regard, it is necessary to establish additional infrastructure facilities that create necessary conditions for strengthening innovative development of the region, and this also affects the fact that the third and fourth groups of indicators in the region are in the significant and moderate risk zones.

\section{Assessment of the effectiveness of infrastructure facilities to support scientific, technical and innovation activities of the Republic of Sakha (Yakutia)}

In terms of the level of infrastructure development the Republic of Sakha (Yakutia) is similar to the region studied above, however, in contrast to Volgograd Oblast, the generalised index of the infrastructure for supporting scientific, technical and innovation activities is in the stability zone. The factors influencing this result are to be analysed. 
Analysing the regulatory framework, it is worth noting that there was no state programme from 2009 to 2011 and its development in 2012. The tasks of the programme, as well as in other regions, were to promote innovative and technological development and to form competitive economy through the development of regional infrastructure for supporting scientific, technical and innovation activities. The main elements of the infrastructure for supporting scientific, technical and innovation activities of the Republic of Sakha (Yakutia) are given in Table 11.

Table 11

Distribution of infrastructure facilities to support scientific, technical and innovation activities by elements in the Republic of Sakha (Yakutia)

\begin{tabular}{|lllllllllll|}
\hline Element & $\mathbf{2 0 0 9}$ & $\mathbf{2 0 1 0}$ & $\mathbf{2 0 1 1}$ & $\mathbf{2 0 1 2}$ & $\mathbf{2 0 1 3}$ & $\mathbf{2 0 1 4}$ & $\mathbf{2 0 1 5}$ & $\mathbf{2 0 1 6}$ & $\mathbf{2 0 1 7}$ & $\mathbf{2 0 1 8}$ \\
\hline Financial & 1 & 1 & 2 & 2 & 2 & 2 & 2 & 2 & 2 & 2 \\
\hline $\begin{array}{l}\text { Production } \\
\text { and } \\
\text { technological }\end{array}$ & 8 & 8 & 9 & 11 & 11 & 12 & 13 & 15 & 17 & 19 \\
\hline $\begin{array}{l}\text { Information } \\
\text { Expert and }\end{array}$ & 1 & 1 & 1 & 1 & 1 & 1 & 1 & 1 & 1 & 1 \\
\hline consulting & 1 & 1 & 1 & 1 & 1 & 1 & 1 & 1 & 1 \\
\hline $\begin{array}{l}\text { Personnel } \\
\text { Sales }\end{array}$ & 1 & 9 & 9 & 6 & 7 & 7 & 7 & 7 & 7 & 7 \\
\hline $\begin{array}{l}\text { Optimality of } \\
\text { infrastructure } \\
\text { support }\end{array}$ & 0.818 & 0.870 & 0.957 & 0.875 & 0.917 & 1.000 & 1.087 & 1.000 & 1.036 & 1.107 \\
\hline
\end{tabular}

Since 2014, there has been an increase in the number of support infrastructure facilities in the production and technological element, which indicates the presence of a set of measures aimed at the region's development.

In addition to business incubators, there are shared resource centres on the basis of educational institutions, as well as technoparks, such as "Yakutia" and "Neryungri" in the territory of Yakutia, created with the aim to commercialise innovative projects and transfer new technologies.

Considering the indicators of the group of potential in creating innovations, it can be seen that all of them were in the moderate risk zone, close to the stable one. This is connected with the fact that there is a sufficient ratio of government expenditure on education and GRP in the Republic, thus there is a high proportion of researchers with a scientific degree. However, at the same time, it is possible to see a low proportion of personnel engaged in research and development. This may be connected with the direct specialisation of the entity focused on the extractive industry, which occupies more than $50 \%$ of the GRP structure. In this regard, there is a low value of the inventive activity coefficient, as well as the share of innovative goods, works, services. 
Considering the generalised indices of the infrastructure for supporting scientific, technical and innovation activities, it can be noted that all of them are in the stability zone.

There is all the necessary regulatory framework in the region that establishes the foundations of innovative development and the functioning of the infrastructure to support scientific, technical and innovation activities. Thus, for this block, it can be noted that the region is in the stability zone.

Each of the types of support infrastructure elements is represented in the region and, in this way, the innovation cycle is closed. Based on Table 12, it can be concluded that no changes have been observed in the majority of elements for several years, with the exception of production and technology element.

Table 12

Distribution of infrastructure facilities to support scientific, technical and innovation activities by elements in Bryansk Oblast

\begin{tabular}{|lllllllllll|}
\hline Element & $\mathbf{2 0 0 9}$ & $\mathbf{2 0 1 0}$ & $\mathbf{2 0 1 1}$ & $\mathbf{2 0 1 2}$ & $\mathbf{2 0 1 3}$ & $\mathbf{2 0 1 4}$ & $\mathbf{2 0 1 5}$ & $\mathbf{2 0 1 6}$ & $\mathbf{2 0 1 7}$ & $\mathbf{2 0 1 8}$ \\
\hline Financial & 1 & 1 & 3 & 3 & 3 & 3 & 3 & 3 & 3 & 3 \\
\hline $\begin{array}{l}\text { Production } \\
\text { and } \\
\text { technological }\end{array}$ & 2 & 2 & 4 & 6 & 6 & 6 & 7 & 7 & 8 & 9 \\
\hline $\begin{array}{l}\text { Information } \\
\text { Expert and }\end{array}$ & 1 & 1 & 1 & 1 & 1 & 1 & 1 & 1 & 1 & 1 \\
\hline consulting & 2 & 2 & 3 & 3 & 3 & 3 & 3 & 3 & 3 \\
\hline $\begin{array}{l}\text { Personnel } \\
\text { Sales }\end{array}$ & 1 & 1 & 1 & 1 & 1 & 1 & 1 & 1 & 1 & 1 \\
\hline $\begin{array}{l}\text { Optimality of } \\
\text { infrastructure } \\
\text { support }\end{array}$ & 0.856 & 1.034 & 1.043 & 0.898 & 0.898 & 0.922 & 0.823 & 0.895 & 0.824 & 0.779 \\
\hline
\end{tabular}

However, after calculating the indicator equal to the ratio of infrastructure facilities for supporting scientific, technical and innovation activities and the number of organisations carrying out research and development, the result demonstrated that the number of elements is close to the number of innovative enterprises performing research and development. This trend may be a reason for the stagnation of some infrastructure facilities for supporting scientific, technical and innovation activities due to their excessive number in comparison with the number of the above-mentioned enterprises, as well as indicate of ineffectiveness of such infrastructure functioning due to reduction in the number of organisations engaged in research and development.

There is a problem of the personnel element in the region, associated with the extremely low number of personnel engaged in research and development. However, despite this, there is a big share of innovative products and the share of developed advanced manufacturing technologies in the total volume of the used ones. Based on this, it can be assumed that the elements of the infrastructure for supporting scientific, technical and innovation activities, presented in greater numbers in relation to one innovation enterprise than in other regions, give a positive result in the innovative development of the economy. 
Summarising the methodology testing, it is worth noting that a high value of the generalised integrated index does not always indicate the absence of problems in certain groups of indicators, and a region that is an integral leader may lose to an average region in certain indicators. Therefore, for a comprehensive analysis and selection of effective practices for innovative development of regions, it is necessary to consider each group of indicators in detail. The methodology used gives an opportunity to form both a generalised integrated index and to analyse the efficiency of the infrastructure functioning by specific indicators.

\section{Conclusions}

As a result of the methodology testing, it is possible to note its effectiveness in determining the bottlenecks of the quantitative and qualitative sufficiency of infrastructure facilities for supporting science and innovation in the region, as well as the fact that the synergy effect arises with their optimal balance, which gives positive effects reflected in the achievement of threshold values for other groups of indicators, however, this effect is less than expected. At the same time, the synergy effect from the support infrastructure activities gives the methodology an opportunity to consider the innovation cycle closedness and the way innovation is supported at various stages of technological transfer in a particular region. It should be noted that a lot of support infrastructure facilities do not always mean its effective functioning.

The regulatory component assessment has also confirmed its relevance. As a result, in the periods where there were problems with legislation in the field of innovation in the regions under consideration, a decrease in the result indicators of innovation development was noted (third and fourth groups of indicators). Allocation of regulatory support indicators into a separate group made it possible to identify weaknesses and blind spots (almost in every analysed region) in regional legislation that hinder innovative progress.

\section{Abbreviations}

COVID-19 - COronaVIrus Disease 2019

BRICS - Brazil, Russia, India, China, South Africa

R\&D - Research and development

EU - The European Union

NIAC MIIRIS - National Information and Analytical Center for Monitoring the Innovative Infrastructure of Scientific and Technical Activities and Regional Innovation Systems

RF - Russian Federation

GRP - Gross Regional Product

RA - Rating Agency

RFBR - Russian Foundation for Basic Research 


\section{Declarations}

\section{Availability of data and material}

All data generated or analysed during this study are included in this published article

\section{Competing interests}

The authors declare that they have no competing interests to declare

\section{Funding}

The reported study was funded by RFBR, project no. 20-010-00482.

\section{Authors' contributions}

All authors read and approved the final manuscript

\section{Acknowledgements}

Not applicable

\section{References}

1. Adam Smith International [Electronic resource]: Measuring and Maximising Value for Money in Infrastructure Programmes (2012). Available at: http://assets.publishing.service.gov.uk

2. Ascani, A., Bettarelli, L., Resmini, L., \& Balland, P. (2020). Global Networks, Local Specialisation and Regional Patterns of Innovation, In Research Policy, 49 (8)

3. Barinova, V. A., Maltceva, A. A., Sorokina, A. V., \& Eremkin, V. A. (2014). Approaches to Assessing the Adequacy and Efficiency of the Innovation Infrastructure Facilities in Russia. In Innovations, 3(185), 42-51

4. Bell, Đ., Chetty, R., Jaravel, X., Petkova, N., \& Reenen, J. V. (2019). Who Becomes an Inventor in America? The Importance of Exposure to Innovation. The Quarterly Journal of Economics, 134(2), 647-13

5. Bezpalov, V. V., Fedyunin, D. V., Solopova, N. A., Avtonomova, S. A., \& Lochan, S. A. (2019). A Model for Managing The Innovation-Driven Development of A Regional Industrial Complex. Entrepreneurship and Sustainability Issues, 6(4), 1884-1896

6. Bondarenko, V. V., Chakaev, R. R., Leskina, O. N., Tanina, M. A., Yudina, V. A., \& Kharitonova, T. V. (2018). The Role of Regional Development Institutions in Enhancing The Innovation Potential of The Constituent Entities of The Russian Federation. Regional Economics: Theory and Practice, 16(1), 83100

7. Bondarev, S. A., \& Turina, V. Y. (2011). Regulatory Support Innovation in The Russian Federation. In SSTU Bulletin, 2(60), 345-349 
8. Carrazza, S., Ferrara, A., \& Salini, S. (2014). Research Infrastructures in the LHA Era: A Scientometric Approach, In Milan European Economy Workshops Working Papers, 2014-12

9. Colombelli, A., Grilli, L., Minola, T., \& Mrkajic, B. (2020). To What Extent Do Young Innovative Companies Take Advantage of Policy Support to Enact Innovation Appropriation Mechanisms? In Research Policy, $49,1-17$

10. Crossing The Next Regional Frontier [Electronic resource]: Information and Analytics Linking Regional Competitiveness to Investment in a Knowledge-Based Economy. U. S. Economic Development Administration (2009). Available at: http://www.statsamerica.org/innovation

11. Dalekin, P. I. (2018). Improvement of Standard Legal Support of Innovative Activity in The Russian Federation, In Proceedings of Voronezh State University. Series: Law, 3, 45-54

12. Del Bo Ch. The Rate of Return to Investment in R\&D Infrastructure: An Overview, In Milan European Economy Workshops Working Papers, 2014-11

13. Fang, C., Ma, H., Wang, Z., et al. (2014). The Sustainable Development of Innovative Cities in China: Comprehensive Assessment and Future Configuration. Journal of Geographical Sciences, 24, 10951114

14. Filipishyna, L., Bessonova, S., \& Venckeviciute, G. (2018). Integral Assessment of Developmental Stability: Cases of Lithuania and Ukraine. Entrepreneurship and Sustainability Issues, 6(1), 87-99

15. Firsova, Đ. Đ., Makarova, E. L., \& Tugusheva, R. R. (2020). Institutional Management Elaboration through Cognitive Modeling of the Balanced Sustainable Development of Regional Innovation Systems. Journal of Open Innovation: Technology, Market, and Complexity, 6(2), 32

16. Florio, M., \& Sirtori, E. (2014). The Evaluation of Research Infrastructures: A Cost-Benefit Analysis Framework, In Milan European Economy Workshops Working Papers, 2014-10

17. Gokhberg, L. M., et al. (2020). The Rating of Innovative Development of The Constituent Territories of The Russian Federation: Analytical Report, (6) (pp. 264). Moscow, the National Research University Higher School of Economics

18. Ivanova, I., Strand, O., \& Leydesdorff, L. (2019). The Synergy and Cycle Values in Regional Innovation Systems: The Case of Norway. Journal of the National Research University Higher School of Economics, 13(1), 48-61

19. Ivashchenko, N. P., \& Denisova, S. A. Innovation Process and Forms of Innovation Commercialisation. Academic Material. [Electronic resource]. Available at: https://www.msu.ru

20. Khuchbarov, A. U. (2015). Human Capital as A Factor of Regional Development, In Humanities, Socialeconomic and Social Sciences, 10-2, 72-75

21. Kiškis, M., Limba, T., \& Gulevičiūtè, G. (2016). Business Value of Intellectual Property in Biotech SMEs: Case Studies of Lithuanian and Arizona's (US) Firms, In Entrepreneurship and Sustainability Issues, 4(2), 221-234. https://doi.org/10.9770/jesi.2016.4.2(11)

22. Koroleva, L. P., \& Ermoshina, T. V. (2014). Innovation Infrastructure: Composition and Place in The Innovation System of The Economy, In Innovations, 2 (194), 59-61 
23. Kremer, M. (2020). Experimentation, Innovation, and Economics. American Economic Review, 110(7), 1974-94

24. Kudriavtseva, S. S. (2012). Comparative Analysis of Innovative Development of The European Union Countries and Russia (Based on the European Innovation Scoreboard Methodology) - Problems of Raw Economies. Bulletin of The Technological University, 15(19), 204-208

25. Laužikas, M., Miliūtè, A., Tranavičius, L., \& Kičiatovas, E. (2016). Service Innovation Commercialization Factors in the Fast Food Industry. Entrepreneurship and Sustainability Issues, 4(2), 108-128

26. Loginov, K. K. (2015). Analysis of Indicators of Regional Economic Safety. The Russian Automobile and Highway Industry Journal, 2(42), 132-139

27. Mel'nikov, R. (2015). Foreign Approaches to Assessing the Efficiency of Investment in Innovation Infrastructure and Their Possible Application in Russia, In Economic Analysis: Theory and Practice, 14 (41), 23-34

28. Mityakov, E. S. (2018). Development of Methodology and Tools for Monitoring the Economic Security of Russian Regions (Thesis for the Degree of the Doctor of Economics), Nizhny Novgorod, $360 p$

29. Mityakov, E. S., \& Mityakov, S. N. (2014). Adaptive Approach to Calculation of The Generalized Index of Economic Security. Modern Problems of Science and Education, 2, 415-421

30. Official Website of Association of Innovative Regions of Russia [Electronic resource]. Available at: https://i-regions.org/

31. Official Website of The Rating Agency "Expert RA" [Electronic resource]. Available at: https://www.raexpert.ru

32. Official Website of The Rating Agency "RIA Rating" [Electronic resource]. Available at: https://riarating.ru

33. Pan'shin, I. V., \& Kashitsyna, T. N. (2009). Improving the methodology for the component assessment of the level of the regional innovation infrastructure development. In Regional Economics: Theory and Practice, 30(123), 43-53

34. Parrilli, M. D., Balavac, M., \& Radicic, D. (2020). Business Innovation Modes and Their Impact on Innovation Outputs: Regional Variations and The Nature of Innovation Across EU Regions. In Research Policy, 49, (8)

35. Porosyatnikova, N. A. (2011). Information and Methodological Support for the Development of Innovation Infrastructure at The Meso-Level: Case Study: Saratov Oblast' (Abstract of The Thesis for the Degree of the Candidate of Economics), Saratov, 22

36. Rezk, M. A., Ibrahim, H. H., Radwan, A., et al. (2016). Innovation Magnitude of Manufacturing Industry in Egypt with Particular Focus on SMEs. Entrepreneurship and Sustainability Issues, 3(4), 307-318

37. Rezk, M. A., Ibrahim, H. H., Tvaronavičienè, M., et al. (2015). Measuring Innovations in Egypt: Case of Industry. Entrepreneurship and Sustainability Issues, 3(1), 47-55

38. Ruiga, I. R., Byvshev, V. I., \& Panteleeva, I. A. (2019). Evaluation of Efficiency of Regional Innovation Infrastructure: Formation of Methodological Principles and Performance Indicators. Innovative Development of Economy, 2(50), 62-71 
39. Rumyantsev, A. A. (2015). Science and Innovation Space of a Macroregion: Prospects of Innovative Territorial Development, In Studies on Russian Economic Development, 26 (4), 379-387. DOI: $10.1134 /$ S1075700715040097

40. Semenov, E. V. (2007). Human Capital in the Field of Science. International Organisations Research Journal, 2(4), 24-39

41. Veselovsky, M. Y., Izmailova, M. A., Lobacheva, E. N., Pilipenko, P. P., \& Rybina, G. A. (2019). Strategic Management of Innovation Development: Insights Into A Role of Economic Policy. Entrepreneurship and Sustainability Issues, 7(2), 1296-1307

42. Website of the National Information and Analytical Center for Monitoring the Innovative Infrastructure of Scientific and Technical Activities and Regional Innovation Systems [Electronic resource]. Available at: http://www.miiris.ru

43. Zollo, G., Autorino, G., De Crescenzo, E., et al. (2011). A Gap Analysis of Regional Innovation Systems (ris) With Medium-Low Innovative Capabilities: The Case of Campania Region (Italy), In 8th ESU Conference on Entrepreneurship, 1-21

\section{Figures}

\section{Stages of the innovation process}

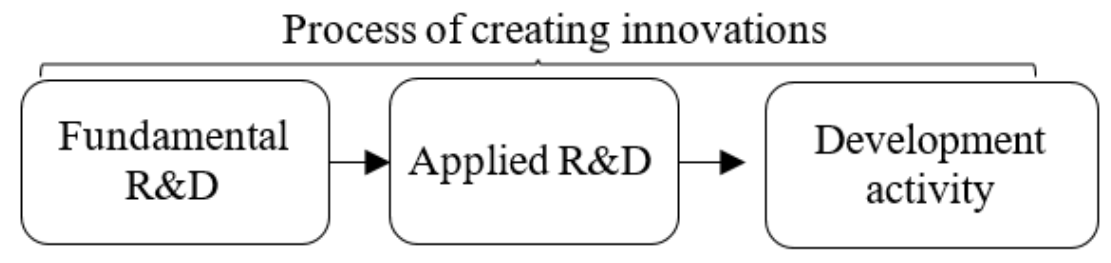

Process of innovations commercialisation

Production and technological, information, financial, expert and consulting

Personnel

Sales

Figure 1

Stages of the innovation process 


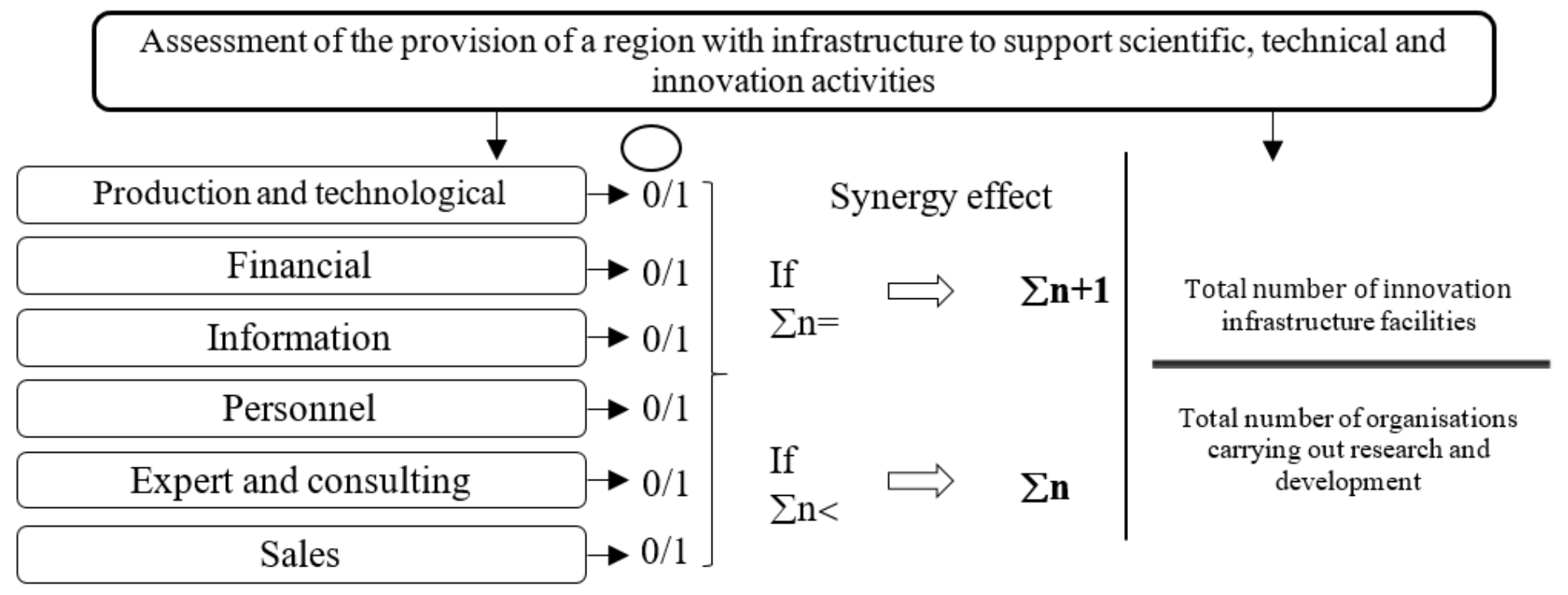

Figure 2

Assessment of the provision of a region with the infrastructure to support scientific, technical and innovation activities

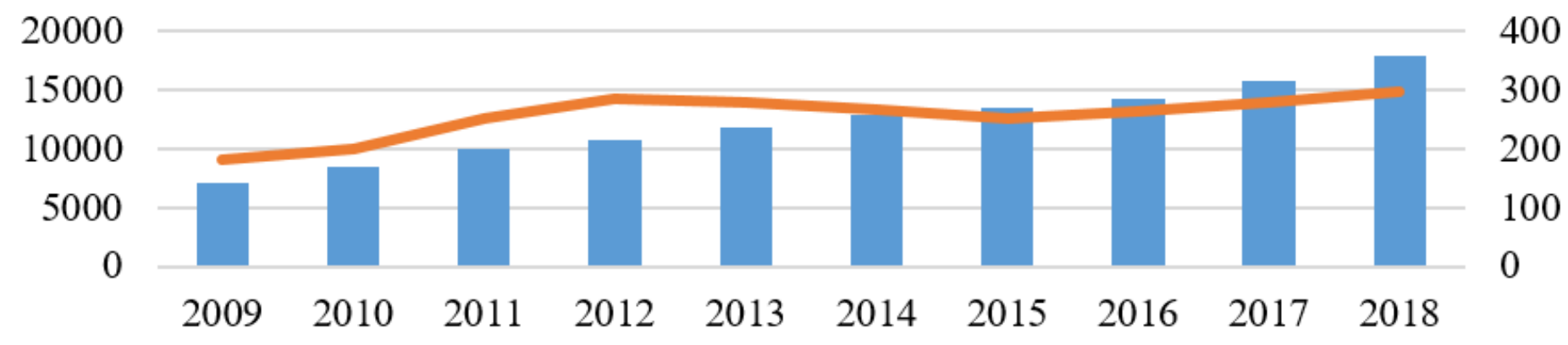

GRP, bn. RUR $\quad$ Expenditure on education, bn. RUR

\section{Figure 3}

The volume of GRP of Moscow and government expenditure on education 


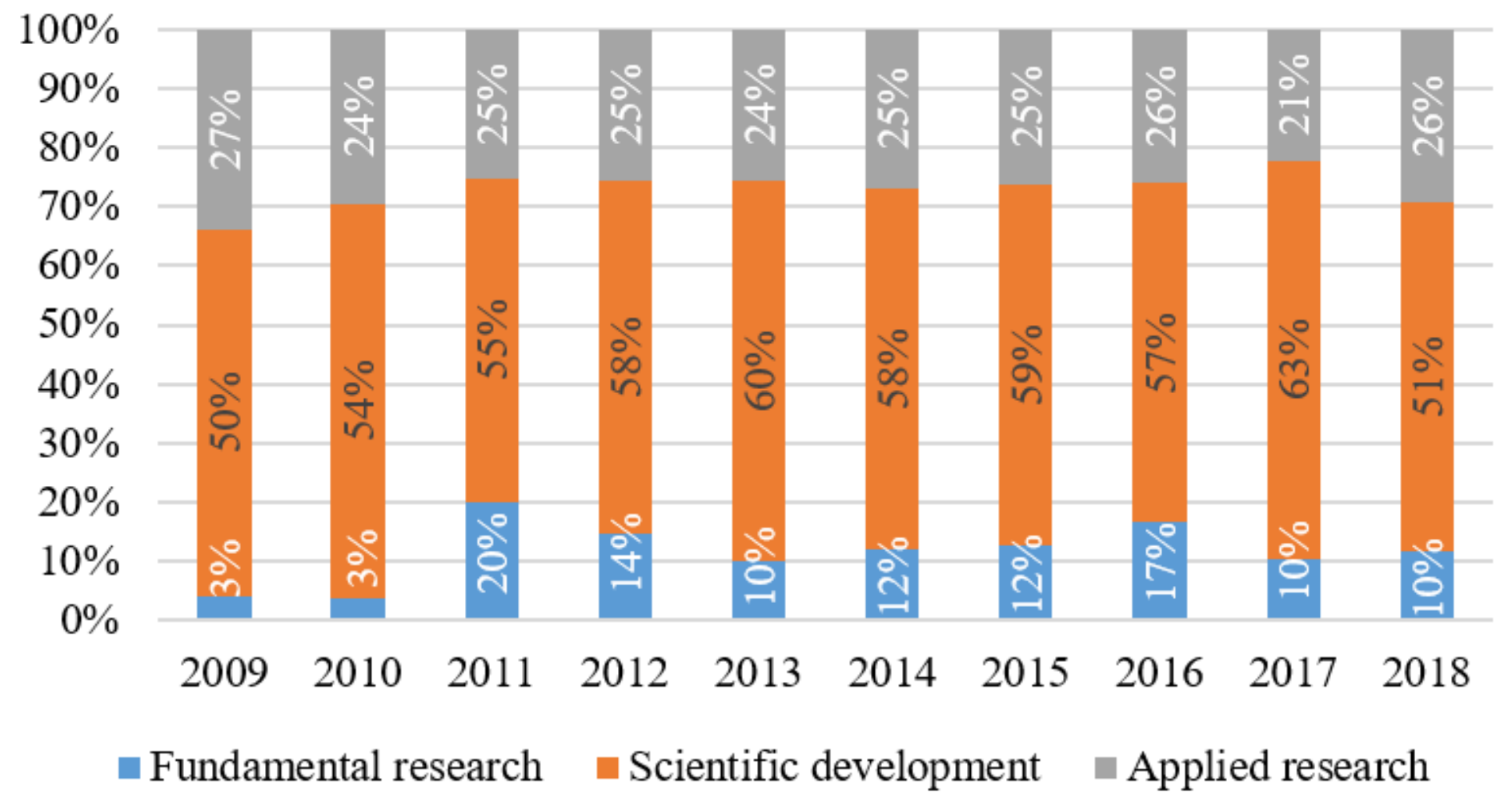

Figure 4

Structure of research and development costs in the total costs of Moscow 